\title{
Sposobnost slovenskega parlamenta sodelovati $v$ procesu odločanja na ravni EU
}

\author{
UDK: $328.3(497.12): 341$ \\ Drago Zajc \\ Fakulteta za družbene vede, Univerza v Ljubljani \\ drago.zajc@fdv.uni-lj.si
}

\begin{abstract}
IZVLEČEK
Razvoj EU je ustvaril posebno vrsto 'delegirane demokracije', v kateri imajo večjo moč izvršilna telesa, medtem ko imajo nacionalni parlamenti le možnost posrednega vplivanja in nadzora svojih vlad, ko le-te sodelujejo $v$ procesih odločanja na ravni EU. Parlamenti držav članic EU so se v novem okolju znašli različno, saj nekateri dovolj dobro izkoriščajo možnosti sodelovanja s svojimi vladami, kar pa je odvisno od vrste okoliščin in različnih dejavnikov. Državni zbor se je kot nov parlament samostojne države na svojo novo vlogo dovolj dobro pripravil že med pripravami na vključitev, saj je kot edini parlament držav kandidatk potrjeval pogajalska stališča. Zelo dobra je tudi njegova formalna in organizacijska pripravljenost (institutional capacity), medtem ko mu primanjkuje praktičnega znanja in izkušenj (cultural capacity).
\end{abstract}

Ključne besede: parlamentarizem, demokracija, EU, organizacijska pripravljenost, organizacijske izkušnje

\section{Položaj nacionalnega parlamenta $v$ institucio- nalnem modelu EU}

Razvoj evropske integracije je, spodbujen z intenzivnimi procesi globalizacije in internacionalizacije, $\vee$ katerih sta naraščali medsebojna povezanost in soodvisnost nacionalnih držav, ustvaril povsem nove nadnacionalne evropske institucije in posebna razmerja odgovornosti, ki se razlikujejo od klasičnega nacionalnega tipa predstavniške demokracije. To je logičen rezultat dejstva, da so imele pri oblikovanju teh institucij prvenstven vpliv nacionalne politične elite in vlade, ki so ob sodelovanju nekaterih interesnih skupin usmerjale institucionalni razvoj od zgoraj navzdol, medtem ko so bili nacionalni parlamenti marginalizirani. Zaradi določenih zgodovinskih predpostavk in ustaljenih načinov dela ti 


\section{Drago Zajc \\ Sposobnost slovenskega parlamenta sodelovati $v$ procesu odločanja na ravni EU}

parlamenti pogosto tudi sami niso kazali velikega zanimanja za 'zunanje' zadeve. Nacionalne elite in njihovi voditelji pa so $v$ želji za doseganjem hitrih odločitev dajali prednost učinkovitosti odločanja na račun odprtega in široko razumljivega demokratičnega procesa tehtanja argumentov in iskanja sporazuma. Takšen asimetričen tip oblikovanja novih nadnacionalnih institucij je ustvaril posebno vrsto 'delegirane demokracije', sestavljene iz pristojnosti, ki so bile prenesene nanjo predvsem iz nacionalnih parlamentov. Te pristojnosti so bile porazdeljene med različne institucije, katerim primanjkuje demokratične legitimnosti (input legitimacy). Na ravni EU se tako pojavlja poseben tip 'izvršnega federalizma', ki $\vee$ svetovni zgodovini nima primerjave in $\vee$ katerem imajo pomembno moč institucije z izvršilno močjo oz. nacionalne vlade (Dann, 2000), katerih predstavniki so $\vee$ Svetu ministrov'. Zakonodajna iniciativa je $v$ rokah Evropske komisije, ki je izvršilno telo, neodvisno od večine $v$ Evropskem parlamentu, sestavljena pa je iz političnih funkcionarjev. Določeno vlogo $v$ zakonodajnem procesu ima - skupaj s Svetom ministrov - edino neposredno izvoljeno predstavniško telo, Evropski parlament, katerega legitimnost je vprašljiva z vidika padajoče udeležbe na volitvah vanj. Od nacionalnih parlamentov pa se bistveno razlikuje tudi po tem, da ne postavlja evropske vlade.

Zaradi marginalizacije nacionalnih parlamentov in številnih pomanjkljivosti $\checkmark$ delovanju institucij EU, katerih legitimnost je pomanjkljiva, je prišlo do vrste poskusov, kako okrepiti ali celo nadomestili njihovo zmanjšano vlogo. Že I. 1989 so predstavniki evropskih parlamentov $\vee$ Parizu ustanovili Konferenco odborov za evropske zadeve (COSAC), ki naj bi okrepila sodelovanje med parlamenti in $\mathrm{s}$ tem povečala njihov pomen. $V$ devetdesetih letih je nato prišlo do določene rehabilitacije nacionalnih parlamentov, ki so dobili večji vpliv prek svojih vlad. Sprejeta je bila vrsta novih pogodb in deklaracij, ki so dejansko ustvarile novo parlamentarno klimo. Vloga nacionalnih parlamentov je bila priznana že z maastrichtsko pogodbo, sprejeto I. 1992, ki je sicer prenesla na raven EU številne pristojnosti. Kljub temu, da je bila njena Deklaracija št. 13 o nacionalnih parlamentih predvsem politične narave, je prispevala $k$ nadaljnji pravni ureditvi vloge nacionalnih parlamentov in omogočila njihov večji vpliv. $V$ Protokolu št. 9 amsterdamske pogodbe iz I. 1997, ki je institucionalno spremenila maastrichtsko pogodbo, je bila nacionalnim parlamentom dodeljena dejanska formalnopravna vloga nadzornikov svojih vlad, ko te sodelujejo $v$ procesu

1 Nekateri avtorji opozarjajo, da EU, kakršna se je izoblikovala, ni niti nadnacionalna organizacija, niti organizacija suverenih držav, temveč je nekakšna struktura sui generis (Norton, 2001: 3). Še najbolj naj bi ustrezala načelom konsociativne demokracije, ki upošteva sporazume med elitami, hkrati pa naj bi bil opazen tudi francoski tehnokratski pristop in nezaupanje $v$ parlamentarno odločanje ( $k i$ naj bi uničilo 4 . in 5 . republiko). Skupno tem idejam je nasprotovanje parlamentarnemu pojmovanju neposredne odgovornosti, kar se je dejansko uresničilo - institucionalizacijo EU je spremljal proces dejanske deparlamentarizacije. 


\section{Drago Zajc procesu odločanja na ravni EU}

odločanja na ravni EU, čeprav je bila ureditev načina nadzora prepuščena ustavni ureditvi oz. običajem vsake države članice. Protokol je podrobneje uredil način obveščanja parlamentov (vse dokumente o delu komisije je treba dostaviti nacionalnim parlamentom) in rok, ki mora poteči med vložitvijo zakonodajnega predloga komisije in dnem, ko se ta uvrsti na dnevni red. Prav tako je dodatno opredelil vlogo Konference odborov za evropske zadeve. Države članice so k amsterdamski pogodbi sprejele tudi Protokol o uporabi načel subsidiarnosti in sorazmernosti.

Pomen nacionalnih parlamentov je bil nato ponovno poudarjen na zasedanju Sveta Evrope v Nici decembra 2000 oz. v Deklaraciji št. 23 o prihodnosti EU. Deklaracija je poudarila potrebo po izboljšanju demokratične legitimnosti EU in preglednosti delovanja njenih institucij, z namenom, da bi jih približali državljanom držav članic. Pri tem je posebej poudarila krepitev vloge nacionalnih parlamentov kot enega strateških vprašanj celotne EU in se zavzela za širšo razpravo o prihodnosti EU, $v$ kateri naj bi sodelovali tudi predstavniki nacionalnih parlamentov. Naslednja deklaracija, ki jo je Evropski svet sprejel na zasedanju $\vee$ Laekenu I. 2001, je med drugim obravnavala vprašanje razmerij med institucijami EU ter preglednosti njihovega delovanja z vidika učinkovitosti. Hkrati je ponovno poudarila vlogo nacionalnih parlamentov kot institucij, ki naj prispevajo k večji legitimnosti in demokratičnosti odločitev. Deklaracija je tudi vzpostavila posebno Konvencijo o prihodnosti Evrope z nalogo, da pripravi predloge institucionalnih reform, kar se je dejansko zgodilo. Glede na to, da je bila ena od nalog konvencije tudi opredelitev vloge nacionalnih parlamentov $v$ sedanjem evropskem institucionalnem modelu, je pomembno, da so kar dve tretjini članov konvencije so sestavljali poslanci nacionalnih parlamentov in Evropskega parlamenta.

Krepitev vloge nacionalnih parlamentov $v$ obstoječem institucionalnem modelu ni bilo zgolj formalno prizadevanje z namenom nadomestiti pomanjkanje demokratične legitimnosti institucij EU, ampak je dalo nekaj otipljivih rezultatov oz. odprlo vrsto možnosti in konkretnih načinov za povečanje njihovega vpliva, čeprav na posreden način, to je prek nacionalnih vlad ${ }^{2}$.

2 Pri izgrajevanju institucionalnega modela EU so se sicer brez uspeha pojavljale tudi ideje o neposrednejšem sodelovanju nacionalnih parlamentov v zakonodajnem procesu na ravni EU z možnostjo neposrednih posegov v pristojnosti institucij EU. Med njimi je bil posebno zanimiv predlog o uvedbi senata nacionalnih parlamentov, ki bi opravljal funkcijo drugega doma. Te pobude so bile dosledno zavračane, saj je tudi Evropski parlament I. 1997 sprejel posebno resolucijo, s katero je zavrnil možnost formalnega sodelovanja nacionalnih parlamentov pri izvrševanju suverenih pravic, ki so jih države članice prenesle na EU. Sodelovanje med Evropskim parlamentom in nacionalnimi parlamenti tako poteka samo na skupnih sejah stalnih delovnih teles nacionalnih parlamentov in Evropskega parlamenta, na skupnem zasedanju parlamentov držav članic in Evropskega parlamenta (Assises) in v obliki Konference predsednikov parlamentov. 
Drago Zajc

\section{Sposobnost slovenskega parlamenta sodelovati v} procesu odločanja na ravni EU

\section{Vloga nacionalnega parlamenta $v$ procesu odločanja na ravni EU}

Čeprav formalne pristojnosti nacionalnih parlamentov držav članic EU letem ne omogočajo neposrednega sodelovanja $\vee$ zakonodajni dejavnosti na ravni EU, je njihova naloga preverjanja odgovornosti svojih vlad, ko le-te sodelujejo $v$ procesih odločanja, nadvse pomembna. Nadzor nad vlado, ki sodeluje $v$ pripravah odločitev na ravni EU, je politično in psihološko najpomembnejša naloga sodobnih nacionalnih parlamentov držav članic, še posebej, ker imajo parlamenti hkrati možnost sodelovanja z vlado pri oblikovanju in pripravi stališč. Nacionalnemu parlamentu ostajajo na razpolago vsa sredstva nadzora s sankcijami, kot so interpelacije, nezaupnice, itd. Pogosto se spregleda, da lahko parlament na ta način $v$ določeni meri kompenzira izgubo pristojnosti in $z$ ustreznimi postopki postane sooblikovalec evropskih zakonov, ki se sprejemajo $\checkmark$ zakonodajnih telesih EU (Svet ministrov in Evropski parlament), oz. celih politik na posameznih področjih, ki poleg prebivalcev Slovenije zavezujejo vse članice EU oz. so obvezne za vseh 450 milijonov državljanov EU (Igličar, 2005). Na drugi strani naj bi bile nacionalne vlade za tako sodelovanje same zainteresirane, saj lahko v pogajanjih nastopajo s preverjenimi in trdnejšimi stališči.

Potreba po parlamentarnem nadzoru $v$ primerih, ko gre za nadzor nad sodelovanjem vlad $v$ procesih odločanja na ravni EU, je na eni strani povezana $z$ dejstvom, da imajo pristojnosti, ki so bile odvzete tem parlamentom in prenesene na raven EU, izjemno velik simboličen pomen, saj se je država odpovedala pomembnemu delu svojih suverenih pravic. Na drugi strani ima zakonodaja EU velik pomen za nacionalno zakonodajo, saj ima prednost pred pravom držav članic. Poenotenje prava EU že poteka na dva načina, kot unifikacija in harmonizacija prava - $v$ prvem primeru z uredbami Sveta ministrov, ki se neposredno uporabljajo $v$ vseh državah članicah EU, $v$ drugem primeru pa se z direktivami določajo skupna načela, ki morajo biti enotno uresničena $v$ nacionalnih zakonodajah (osnutek Pogodbe o Ustavi za Evropo uvaja namesto uredbe 'evropski zakon', namesto direktive pa 'evropski okvirni zakon'). Zakonodajna dejavnost na ravni EU je že doslej dosegla izjemen obseg. Po nekaterih ocenah naj bi bilo $v$ bližnji prihodnosti kar $80 \%$ gospodarske in socialne zakonodaje oblikovane na ravni EU. Očitno je, da $v$ takih okoliščinah funkcija nacionalnih parlamentov ni le, da nadzirajo svoje vlade, ampak da tudi sodelujejo z njimi $v$ drugih zadevah, tako da oblikujejo konkretna stališča in splošne smernice, na katera se vladni predstavniki lahko oprejo.

Glede na te predpostavke in na ustvarjeno novo parlamentarno klimo v EU bi bilo pričakovati, da bodo nacionalni parlamenti dejansko izkoristili vse možnosti. Vendar primerjave delovanja nacionalnih parlamentov držav članic EU $\vee$ 
razmerju do EU kažejo, da ta vloga nikakor ni enaka, da je odvisna od njihovih sposobnosti in pričakovanj, oz. da so se vanje zelo različno vživeli. Precej velike razlike se kažejo zlasti med parlamenti sredozemskih in severnoevropskih (skandinavskih) držav. $\vee$ primerjavi z večino parlamentov prejšnjih držav članic EU (z izjemo danskega Folketinga), so parlamenti držav, ki so postale članice leta 1995 (Švedske, Finske in Avstrije) prevzeli zelo aktivno vlogo. Pričakovati je bilo, da si bodo parlamenti novih držav, ki so se vključile ob veliki širitvi I. 2004 (zlasti držav Vzhodne in Srednje Evrope kot so Poljska, Češka, Slovaška, Madžarska in Slovenija), prizadevali prek svojih vlad imeti čim večji vpliv na pripravo odločitev (zakonodajnih aktov), ki se sprejemajo na ravni EU, čeprav ni mogoče ugotoviti, koliko se njihova pričakovanja (in pričakovanja celotne politične elite posameznih držav) ujemajo z razpoložljivimi potenciali in dejanskimi sposobnostmi parlamentov in njihovih članov.

Analiza vlog oz. dejavnosti posameznih parlamentov držav članic EU, ki so bile sprejete pred zadnjo širitvijo, kaže, da so te dokaj različne glede na vrsto nadzora, saj se nekateri parlamenti zadovoljujejo z ex post kontrolo, medtem ko drugi izvajajo aktivno ex-ante kontrolo, ki se pojavlja $v$ obliki predhodnega oz. tekočega sodelovanja z vlado, medtem ko je $v$ številnih parlamentih držav članic najti tudi razne vmesne oblike (Norton, 1995; Maurer in Wessels, 2001). Podrobnejše analize so pokazale, da so te vloge odvisne od vrste dejavnikov, ki imajo včasih le malo skupnega s pričakovanji. Med temi so prav gotovo naslednji:

a) Ustavna vloga parlamenta oz. njegov položaj v političnem sistemu države. Ustave na različne načine določajo ureditev držav in način delitve oblasti. $V$ državah članicah EU, $\vee$ katerih je bolj poudarjena vloga izvršilne oblasti (Francija), običajno parlamenti nimajo pomembnejše vloge.

b) Določena tradicija oblikovanja vlad. V državah, kjer se oblikujejo pretežno enostrankarske vlade ( $V$. Britanija), lahko vlade računajo na zanesljivo podporo $v$ parlamentu. $\vee$ državah, kjer se je uveljavila praksa oblikovanja koalicijskih ali manjšinskih vlad (Danska, Švedska), ki so močno odvisne od parlamentarne podpore, imajo običajno parlamenti velik vpliv na vlado, ko gre za oblikovanje in uveljavljanje nacionalnih stališč. Večji vpliv parlamenta $v$ teh primerih ugotavljajo tudi $v$ državah, kjer koalicijski partnerji težko sodelujejo oz. so sicer večinske vlade šibke.

c) Strankarska kultura in sposobnost sporazumevanja in sodelovanja strank ter oblikovanja skupnih interesov $\vee$ zadevah, ki so nacionalno pomembne. 


\section{Drago Zajc}

\section{Sposobnost slovenskega parlamenta sodelovati $v$ procesu odločanja na ravni EU}

d) Ponekod prisotno tradicionalno pojmovanje, da se z zunanjimi zadevami ukvarja pretežno vlada, $v$ parlamentu pa le nekaj posebej izbranih poslancev, medtem ko so drugi slabo obveščeni oz. se za te zadeve enostavno ne zanimajo.

e) Organizacija dela in še posebej delitev dela med plenum in delovna telesa. Parlamenti so namreč žive institucije, ki se spreminjajo z razvojem oz. izpopolnjujejo svoje organizacijske oblike in način dela s ciljem, da je postopek sprejemanja odločitev čim bolj racionalen in predvidljiv in so končne odločitve čim boljše. Prilagajanje spremenjenim mednarodnim okoliščinam ali uvajanje novih oblik nadnacionalnega sodelovanja običajno terja večje spremembe $v$ organiziranosti in načinu dela, vendar se parlamenti različno odzivajo. $\vee$ vseh državah članicah so se oblikovala nova telesa, ki opravljajo t. i. 'helikoptersko' vlogo in združujejo vse dejavnosti, ki so povezane z zadevami EU.

f) Obseg in kvaliteta strokovne podpore, ki jo imajo na razpolago parlamenti (njihova delovna telesa, skupine poslancev in posamezni poslanci). Strokovne službe parlamentov, svetovalci, itd. lahko pomembno pomagajo poslancem pri iskanju informacij in oblikovanju stališč ter $\mathrm{s}$ tem prispevajo $\mathrm{k}$ bolj usklajenem in hitrejšem delovanju parlamenta ter kvaliteti zakonodaje (legislative continuity). $\mathrm{V}$ parlamentih z boljšo strokovno podporo in razvitim raziskovalnim sektorjem se poslanci lažje prilagajajo zahtevnostim in posebnostim nove vloge.

g) Okoliščine osamosvajanja države, $v$ katerih lahko postanejo zunanji dejavniki odločilni in se vzpostavi tesna prepletenost zunanjih z notranjimi vprašanji.

h) Končni razlog, ki se sicer lahko povezuje s prejšnjimi ali pa deluje samostojno (primer Finske ali Švedske), pa je gotovo aktivna vloga nacionalnega parlamenta $\vee$ procesu vključevanja države $\vee$ EU, zlasti $\vee$ fazi pogajanj oz. pri potrjevanju pogajalskih stališč in na drugi strani pri izredno zahtevnem usklajevanju (harmonizaciji) nacionalne zakonodaje $\mathrm{z}$ acquis communautaire.

Našteti dejavniki, ki so jih ugotavljali raziskovalci sodobnih parlamentov, in njihove vloge $\vee$ EU (Norton, 1995; Agh, 2001) v veliki meri pojasnjujejo tudi vlogo parlamentov post-socialističnih držav Vzhodne in Srednje Evrope, ki so postale članice ob zadnji širitvi EU (2004) in še posebej slovenskega parlamenta. $\vee$ Sloveniji je vloga parlamenta $\vee$ političnem sistemu močnejša, saj je vlada odgovorna državnemu zboru za svoje delo, zakon o vladi pa določa, da je vlada odgovorna za politiko države, ki jo vodi. Ta vloga se je izrazito pokazala $\vee$ teku vključevanja Slovenije $\vee$ EU. Pri tem je prišla do izraza tudi posebna politična 
kultura oz. občutljivost, ko gre za vprašanja suverenosti, ki je povezana z okoliščinami pridobivanja nacionalne samostojnosti.

Čeprav slovenske politične stranke težko sodelujejo in je njihov koalicijski potencial še vedno pomanjkljiv, so prav $v$ tem procesu vključevanja Slovenije našle skupen interes (podpis sporazuma o sodelovanju pri vključevanju Slovenije $\vee$ EU I. 1996), kar je prispevalo k temu, da je Državni zbor RS $\vee$ procesu vključevanja Slovenije $\vee$ EU aktivno razpravljal in potrjeval pogajalska stališča Slovenije, ki jih je Vlada RS zastopala v pogajanjih z Evropsko komisijo. Posamezna stališča so - odvisno od vsebine - obravnavala različna delovna telesa, ki pokrivajo področja oblikovanja javnih politik in oblikovala mnenja, končno stališče pa sta sprejela in posredovala Vladi RS Odbor za zunanjo politiko oz. Komisija za evropske zadeve. Izkušnje iz tega pogajalskega procesa so več kot dobre, saj je bil vseskozi transparenten in pod nadzorom javnosti, naši pogajalci pa so imeli močan mandat in so bili precej uspešni. Na ta način je državni zbor, za razliko od vseh drugih parlamentov držav kandidatk, ki so razpravo o pogajalskih stališčih opravili le $v$ enem specializiranem odboru, to opravil kot celota in bil sproti seznanjen o poteku pogajanj in vsebinskih vprašanjih, o katerih so tekla pogajanja.

S tem je bilo na drugi strani tudi močno olajšano delo pri usklajevanju slovenske zakonodaje s pravnim redom EU. To se je sicer začelo z zamudo, vendar je državni zbor z veliki napori ob sodelovanju z Vlado RS zaostanek hitro nadomestil, čeprav je število usklajenih oz. 'EU- zakonov' predstavljalo v vsakem mandatnem obdobju oz. letu pomemben del vseh sprejetih zakonov. Pri tem usklajevanju, ki je potekalo pod velikimi časovnimi pritiski, je šlo za prevzemanje pravnih norm EU $\vee$ zadostnem obsegu in kvaliteti, pri čemer pa naj bi ohranjali ureditev na tistih področjih, kjer harmonizacija ni bila nujno potrebna. Kljub takim namenom je pogosto prihajalo do mehaničnega prevzemanja pravnih standardov in prepisovanja konkretnih določb. Končni rezultat prilagajanja je bil sicer ugoden - Evropska komisija, ki je v svojih poročilih na začetku navajala številne pomanjkljivosti in težave, je usklajenost slovenske zakonodaje na koncu ocenila kot primerno, Slovenijo pa celo kot najbolje pripravljeno kandidatko.

Preglednica 1: Dinamika usklajevanja slovenske zakonodaje z acquis communautaire v procesu vključevanja Slovenije v EU - število vseh zakonov in število t. i. evropskih zakonov, sprejetih v Državnem zboru RS v posameznih letih

\begin{tabular}{|l|cccccccc|c|}
\hline leto & 1997 & 1998 & 1999 & 2000 & 2001 & 2002 & 2003 & 2004 & skupaj \\
\hline $\begin{array}{l}\text { število vseh } \\
\text { sprejetih zakonov }\end{array}$ & 67 & 74 & 116 & 84 & 111 & 116 & 96 & 113 & 777 \\
\hline $\begin{array}{l}\text { število } \\
\text { 'EU- zakonov' }\end{array}$ & - & 7 & 63 & 59 & 36 & 58 & 36 & 30 & 319 \\
\hline
\end{tabular}

Vir: Državni zbor RS, SVEZ. 


\section{Drago Zajc \\ Sposobnost slovenskega parlamenta sodelovati v procesu odločanja na ravni EU}

Dejavnost Državnega zbora RS pri potrjevanju pogajalskih stališč in v procesu usklajevanja zakonodaje je bila izjemno velikega pomena za celotno njegovo družbeno in politično okolje, saj so se tako državljani lahko seznanjali z načinom delovanja institucij EU in posledicami, ki jih bo vključitev prinesla. Državnemu zboru in samim poslancem je pri tem uspelo nadomeščati pogosto negativne predstave državljanov in volivcev, ki so bile povezane z izkušnjami sobivanja Slovencev $z$ drugimi narodi $v$ večnacionalnih državah, s pozitivnimi predstavami in pričakovanji. $K$ temu so prispevali tudi številni seminarji z udeležbo predstavnikov parlamentov držav članic in držav, ki so se šele pripravljale na vstop in še posebej ustanovitev Foruma za prihodnost Evrope. ${ }^{\mathbf{3}}$ Slovenski državni zbor je $\vee$ fazi vključevanja $\vee$ EU opravil nedvomno izjemno veliko in pomembno delo, kljub številnim težavam, oviram in omejitvam, ki so bile deloma na njegovi strani, med katerimi je bil tudi izredno dolgotrajen in zapleten zakonodajni postopek. Številne ovire in pomanjkljivosti zakonodajnega postopka je vendarle pravočasno odpravil. ${ }^{\mathbf{4}}$ Hkrati je moderniziral tudi svoje strokovne službe in jim določil nove naloge, ustanovil poseben raziskovalni sektor in povečal število strokovnih delavcev ter poskrbel, da so pridobili izkušnje $\vee$ drugih parlamentih držav članic EU. Zato je bilo upravičeno pričakovati, da bo to vlogo obdržal tudi kasneje, to je po formalnem vstopu Slovenije $v$ EU.

\section{Opredelitev sedanje vloge Državnega zbora RS v procesu odločanja na ravni EU in nekatere ugotovitve o delovanju}

Namen slovenskega državnega zbora, da bi imel v pogojih polnopravnega članstva Slovenije EU kolikor mogoče močno, čeprav posredno vlogo v procesih odločanja na ravni EU, se je izkazal že v pripravah na spremembo slovenske ustave, s katero je Slovenija $\vee$ marcu 2003 prenesla na EU precejšen del

3 Forum za prihodnost Evrope, ki ga je Državni zbor RS ustanovil I. 2002, je deloval pod pokroviteljstvom slovenskih članov Konvencije za pripravo predloga ustave EU. Njegova naloga je bila, da pripravi predloge za institucionalno prenovo EU in na drugi strani vzpostavi dialog s civilno družbo. Organiziral je javne razprave, na katerih so svoja stališča predstavili predstavniki nevladnih organizacij, lokalnih in verskih skupnosti ter akademskih krogov. Večji del teh razprav se je ukvarjal z vprašanji, kako zmanjšati demokratični deficit $v$ delovanju institucij EU in na kakšen način povečati vlogo slovenskega parlamenta.

4 Novi poslovnik, sprejet I. 2002, je racionaliziral zakonodajni postopek in moderniziral porazdelitev moči in odgovornosti med udeležence $v$ postopku, kar je prispevalo $k$ temu, da je postal bolj stabilen in predvidljiv. $\mathrm{K}$ njegovemu sprejetju je prispevala tudi Evropska komisija, ki je v svojih letnih poročilih opozarjala na počasnost zakonodajnega postopka. 


\section{Drago Zajc procesu odločanja na ravni EU}

izvrševanja suverenih pravic. ${ }^{\mathbf{5}}$ Tako kot druge države članice, ki so prenos izvedle z ustavnimi spremembami (Avstrija, Belgija, Finska, Francija, Nemčija, Estonija, Madžarska, Slovaška), je tudi Slovenija razmerje med parlamentom in vlado $v$ zadevah EU že na tej ravni dokaj dobro opredelila. Ta sprememba je bila podlaga za naslednje korake $\vee$ smeri priprav na prihodnje delovanje $\vee$ pogojih EU, med katere štejemo sprejem posebnega zakona o sodelovanju državnega zbora in vlade, spremembe poslovnika državnega zbora, oblikovanje posebnega delovnega telesa državnega zbora za zadeve EU, itd.

Pripravljavci spremembe (Ustavna komisija Državnega zbora RS in njena posebna skupina strokovnjakov) so se pri tem zgledovali po evropskih državah, $\checkmark$ katerih imajo parlamenti močno vlogo, ki je zato ustavno kot zakonsko in poslovniško dobro opredeljena. Novi 3.a člen slovenske ustave je namreč določil, da mora vlada sproti obveščati državni zbor, ta pa lahko sprejema stališča, ki jih vlada upošteva pri svojem delovanju. Vlada sicer še naprej samostojno izvaja svojo ustavno vlogo, hkrati pa ima državni zbor pravico in možnost, da neposredno spremlja dejavnost vlade, ko ta sodeluje pri pripravi odločitev in njihovem sprejemanju na ravni EU. S svojimi stališči lahko vpliva na njeno ravnanje oz. jo lahko celo zavezuje k zastopanju posameznih stališč v nacionalnem interesu in jo politično ocenjuje.

Razmerje med državnim zborom in vlado je nato uredil poseben zakon o sodelovanju med državnim zborom in vlado $v$ zadevah EU (podobno sta razmerje med parlamentom in vlado določili tudi Nemčija in Madžarska). ${ }^{\mathbf{6}}$ Zakon izhaja iz ustavne določbe, da vlada ohranja samostojnost pri opravljanju svojih funkcij (čl. 3), državni zbor pa sodeluje pri oblikovanju stališč Republike Slovenije glede zadev EU, ki bi sicer spadale $\vee$ njegovo pristojnost (čl. 4). Vlada je zadolžena oz. nosi odgovornost, da

(a) sproti obvešča državni zbor o vseh zadevah EU, od predlogov aktov in njihovega obravnavanja do njihovega sprejemanja $\vee$ postopkih na ravni EU,

(b) priloži podatke o poglavitnih rešitvah in ciljih posameznih predlogov aktov in postopku njegovega obravnavanja in sprejemanja,

(c) izdela oceno njegovih možnih posledic za slovenski proračun, gospodarstvo, javno upravo, okolje in potrebo po spremembi predpisov, in

(č) poda svoj predlog stališča do predloga (čl. 9).

5 Slovenija je za prenos dela svoje suverenosti, tako kot nekatere druge države, uporabila abstraktni oz. generalni pristop, ki omogoča prenos dela suverenosti na katerokoli mednarodno organizacijo, ki spoštuje človekove pravice.

6 Predlog zakona je vložila 5.12.2003 skupina poslancev s prvopodpisanim A. Anderličem, po vloženi zahtevi, da se zaradi pomembnosti zakona opravi prva obravnava, je bila ta opravljena na 33. redni seji 29.1. 2004. Po opravljeni drugi obravnavi na 34. redni seji 24.2.2004, kjer je bilo $v$ besedilo dodanih nekaj dopolnitev ( $v$ primeru, da se državni zbor ne opredeli do določene zadeve, velja, da se strinja s stališčem vlade), je državni zbor na 35. redni seji 25.3.2005 ob soglasju vseh poslanskih skupin, z izjemo SNS, zakon sprejel z veliko večino (50:7). 


\section{Drago Zajc \\ Sposobnost slovenskega parlamenta sodelovati $v$ procesu odločanja na ravni EU}

To omogoča državnemu zboru, da bistveno hitreje prouči zadevo in vladni predlog potrdi, ali pa spremeni oz. dopolni. Svoje odločitve mora posredovati vladi (člen 10). Konkretno to pomeni, da državni zbor lahko razpravlja o predlogih aktov EU in predlogih stališč, ki jih pripravi vlada, ali pa izrazi namero, da bo o njih razpravljal v danih časovnih rokih, sicer se stališče vlade šteje kot stališče Slovenije. Od vlade se pričakuje, da bo stališča primerno in dosledno uveljavljala $\vee$ procesih odločanja na ravni EU, čeprav ni zavezana $k$ doslednem uveljavljanju, kar bi bila $v$ primeru zavezujočega mandata (zavezujoči mandat se $v$ danskem in avstrijskem primeru ni vedno izkazal za koristnega, ker je vladnim predstavnikom preprečil, da bi vplivali na nadaljnje oblikovanje odločitev $v$ teku pogajanj). Vlada lahko tudi spremeni in dopolni stališče med samimi pogajanji. Poleg tega zakon omogoča državnemu zboru, da na lastno iniciativo, oz. na zahtevo poslancev, odbora za zadeve EU ali kolegija predsednika državnega zbora opravi razpravo o zadevi, ki se mu zdi pomembna in pri tem zavzame stališče. Takšna zahteva mora vsebovati razloge in predlog stališča (člen 11). Enkrat letno pa državni zbor tudi razpravlja o stanju v Evropski uniji na osnovi uvodnega poročila predsednika vlade.

Tako spremenjena oz. dopolnjena vloga državnega zbora je terjala, da svoje pristojnosti prenese na posebni delovni telesi - $v$ primeru zadev EU na Odbor za zadeve EU in v primeru drugih zunanjepolitičnih vprašanj na Odbor za zunanjo politiko. Novi Odbor za zadeve EU, ki naj bi imel 'helikoptersko perspektivo' nad vsemi področji, kjer je bila pristojnost oblikovanja politik prenesena na EU, je bil oblikovan po vzoru na takšna delovna telesa $v$ nekaterih skandinavskih parlamentih, še posebej po vzoru finskega parlamenta, na odbor pristojen za zadeve EU. Odbor mora dobiti mnenja drugih delovnih teles, ki pokrivajo posamezna področja. Zaradi svoje strankarske sestave opravlja odbor tudi druge naloge, med katerimi je tudi čim hitrejše poenotenje glede vprašanj $\vee$ nacionalnem interesu.

Določbe zakona o sodelovanju med državnim zborom in vlado $v$ zadevah EU so nujno terjale tudi spremembe poslovnika državnega zbora. Dopolnitve, ki jih je državni zbor sprejel 20. maja 2004, so podrobneje določile način razprave o zadevah EU, posamezne faze $\vee$ njihovi obravnavi in način izvajanja nalog. Predvidevajo, da bi se odbor sestajal vsak teden, na seje odbora pa naj bi bili vabljeni ministri, predstavniki delovnih teles, predstavniki gospodarstva in drugi strokovnjaki, lahko se jih udeležujejo tudi poslanci $\vee$ Evropskem parlamentu (154 d. in 154 e. člen Poslovnika Državnega zbora RS).

Celoten pravni in institucionalni mehanizem, ki omogoča državnemu zboru, da opravlja svojo vlogo v pogojih članstva Slovenije v EU, je stopil v veljavo in začel delovati, ko je bila Slovenija maja 2004 dejansko sprejeta $\vee$ EU. Vprašanje, ki se postavlja pri tem, je, ali je državnemu zboru dejansko uspelo 
zagotavljanje vseh teh formalnopravnih in institucionalnih pogojev, ali so ti pogoji zadostni za opravljanje aktivne vloge oz. so dejansko izboljšali institucionalno sposobnost (institutional capacity) državnega zbora. Podatkov, ki jih imamo na razpolago za oceno $v$ tem kratkem času ni dovolj, se pa lahko osredotočimo na delovanje glavnega akterja, to je Odbora za zadeve EU, ki je bil oblikovan po volitvah 3. oktobra 2004 (prvi Odbor za zadeve EU, ki je nadomestil prejšnjo Komisijo za evropske zadeve, je državni zbor sicer oblikoval že $v$ maju 2004, a je nehal delovati s koncem 3. mandata državnega zbora).

Novi Odbor za zadeve EU, ki je bil vzpostavljen z odlokom 17. novembra 2004, je opredelil svoje pristojnosti skladno z zakonom o sodelovanju med državnim zborom in vlado $v$ zadevah EU. Delovati je začel precej dinamično in avtonomno in si s tem verjetno že na začetku zagotovil močno vlogo v razmerju do vlade. Že na svoji prvi seji, ki je bila sklicana v času, ko koalicijska vlada še ni bila oblikovana, je zavzel stališče glede predsedovanja Slovenije Evropski uniji v letih 2007 in 2008. Stališče je sicer pripravila že bivša koalicijska vlada, ki je opravljala posle do imenovanja nove vlade. Na osnovi stališča odbora, ki je deloval kot edini decision-maker z vso legitimnostjo in pooblastili za sprejemanje takih odločitev, je nato državni zbor sprejel stališče Slovenije.

Odbor je na svojih številnih sejah (od novembra 2004 do 15. julija 2005 je imel 36 sej, 20 rednih in 16 izrednih) spremljal delo Sveta ministrov in odobraval stališča, ki so jih zastopali predstavniki slovenske vlade na sestankih sveta $\checkmark$ različnih sestavah (Sveta za splošne in zunanje zadeve, Sveta za gospodarske in finančne zadeve, Sveta za kmetijstvo in ribištvo, Sveta za okolje, Sveta za pravosodje in notranje zadeve, Sveta za vzgojo, mladino in kulturo, Sveta za konkurenco in Sveta za zaposlovanje, socialno politiko, zdravje in zaščito potrošnikov). Kadar so bile zadeve EU posredovane drugim delovnim telesom, je odbor prevzemal mnenja teh delovnih teles ali oblikoval lastna mnenja $v$ primerih, ko jih druga telesa niso pripravila (Kraševec, 2005). Odbor je po proučitvi predlogov $\vee$ glavnem $\vee$ celoti podprl stališča vlade, vendar jo je hkrati opozarjal na to, da upošteva mnenja državnega zbora.

Delovanje tega odbora $v$ prvem obdobju kaže, kako so zaživele institucionalne in organizacijske oblike $v$ praksi, kako se je uporabljala strokovna podpora obravnavanju zadev EU in odločanju o njih in tudi, kakšno je bilo angažiranje poslancev $v$ njegovem delu. Pri tem je treba upoštevati sam obseg dela, oz. število obravnavanih točk in število dodeljenih zadev EU. Na drugi strani se pojavlja tudi vprašanje kontinuitete dela $v$ tem telesu, saj je med njegovimi člani le malo takih, ki so bili njegovi člani v prejšnjem mandatnem obdobju oz. so bili člani v katerem od prejšnjih delovnih teles, ki so se ukvarjala z zunanjo politiko ali evropskimi zadevami. Kljub temu mu je $v$ času od njegove vzpostavitve je uspelo vzpostaviti ustrezne načine komuniciranja z vlado in razviti nekatere 
Drago Zajc

Sposobnost slovenskega parlamenta sodelovati $v$ procesu odločanja na ravni EU

delovne metode in način dela - pri tem se je posluževal zlasti prakse kompetentnih delovnih teles iz obdobja, ko se je Slovenija vključevala $\vee$ EU, pripravil je posebno bazo podatkov znotraj informacijskega sistema državnega zbora, ki omogoča poslancem, parlamentarnim službam in akreditiranim novinarjem hiter dostop do dokumentov, itd. (Kraševec, 2005).

Kljub temu, da je imel državni zbor že $\vee$ procesu vključevanja Slovenije $v$ EU izredno pomembno vlogo tudi $\vee$ primerjavi $z$ vsemi drugimi parlamenti držav kandidatk in je že pred sprejemom $\vee$ EU ter neposredno po njem dosegel precej visoko stopnjo institucionalne sposobnosti (institutional capacity) za delovanje v razmerah članstva Slovenije v EU, se postavlja vprašanje njegove subjektivne sposobnosti (cultural capacity). Gre za dejansko razumevanje delovanja EU, njenega razmišljanja in pristopov $k$ oblikovanju skupnih politik glede na interese držav članic (tudi manjših). Pomanjkanje tega razumevanja in poznavanja se je med poslanci sicer že prej večkrat pokazalo $v$ obliki neskladja med načelno podporo EU in njenimi vrednotami ter dejanskim poznavanjem načinov delovanja posameznih institucij, njihovih postopkov odločanja, itd. Ob številnih priložnostih je prihajala do izraza razlika med idealiziranimi predstavami o tem, da bo po vstopu $\vee$ EU odločanje bolj enostavno in pesimističnimi pričakovanji o majhnih možnostih za uveljavljanje slovenskih interesov ali 'potopu' Slovenije $v$ EU. Slovenska parlamentarna elita še ni dovolj razumela, da so evropska vprašanja že postala naša notranja vprašanja, pa tudi, da naša notranja vprašanja lahko postanejo evropska. Po nekaterih ugotovitvah opravljenih raziskav stiki poslancev in poslanskih klubov s poslanci in klubi $v$ drugih parlamentih držav članic EU še niso postali dovolj trdni in sistematični, pridobivanje informacij po teh povezavah pa je sporadično ali redko. Državni zbor naj bi svojo vlogo nacionalnega parlamenta $\vee$ EU premalo krepil tudi z neposrednimi stiki z drugimi parlamenti.

\section{Poskus sklepnih ugotovitev na začetku novega obdobja delovanja slovenskega parlamenta}

Državni zbor se je kot mlad parlament samostojne slovenske države po njeni vključitvi v EU znašel v povsem novem institucionalnem okolju, v katerem veljajo posebna razmerja pristojnosti in odgovornosti, sami nacionalni parlamenti pa lahko le posredno vplivajo na sprejemanje odločitev na ravni EU. Že v času priprav Slovenije na vstop v EU je opravil pomembno vlogo $s$ potrjevanjem pogajalskih stališč, kar je omočilo, da je bil celoten proces pogajanja in vstopanja $\vee$ EU dovolj transparenten in pod nadzorom javnosti. Prav tako se je dobro pripravil na opravljanje svoje prihodnje oz. sedanje vloge. 
Državni zbor je $\vee$ zadnjem času izredno povečal svojo institucionalno sposobnost (institutional capacity). Odnosi sodelovanja in odgovornosti med državnim zborom in vlado so dobro opredeljeni in omogočajo velike možnosti medsebojnega povezovanja in vplivanja na določanje stališč, ki jih zastopa vlada $\vee$ procesih odločanja na ravni EU. Čeprav so nekatere posebne oblike tega sodelovanja, kot je Odbor za zadeve EU, že precej uspešno vzpostavljene (sodeč po številu sej in številu obravnavanih točk dnevnega reda oz. zadev EU ter njihovi vsebinski raznolikosti), pa je $\vee$ tako kratkem času težko sklepati o dejanski učinkovitosti državnega zbora, ki je odvisna tudi od kulturne sposobnosti (cultural capacity). Nedvomno je temu vprašanju treba posvetiti večjo pozornost, saj je $\vee$ EU opazna težnja po povečanju sodelovanja nacionalnih parlamentov, njihova vloga pa se bo še povečala, ko bo stopila $\vee$ veljavo nova ustava.

Posebej pa je treba upoštevati, da se poslanci državnega zbora, kot parlamenta nove države članice, šele uvajajo $v$ svojo novo vlogo, ki terja od njih veliko večje znanje in sposobnosti. To uvajanje je bilo za vse nove države članice posebna težava in tudi parlamentarci držav, ki so postale članice $v$ prejšnjih širitvah, so imeli velike težave, preden so dojeli zahtevnost svojih novih nalog. Pri tem gre tako za (a) sposobnost zaznavanja vprašanj, glede katerih bi morala imeti Slovenija stališče, ki bi ga skušala uveljaviti pri pripravi odločitev $\vee E U$, (b) sposobnost oblikovanja nacionalnih interesov, (c) sposobnost sodelovanja $z$ vlado, ko le-ta sodeluje $v$ procesih odločanja na ravni EU in (č) sposobnost nadzirati vlado in sankcionirati njene nedoslednosti ali napake pri zastopanju slovenskih interesov $v$ EU.

Na osnovi primerjav z drugimi državami članicami EU, zlasti novimi, bi lahko ugotavljali, da se $v$ Sloveniji nasploh premalo razmišlja o zahtevnosti takšnega delovanja slovenskega parlamenta in njegovega sodelovanja $z$ vlado $v$ pogojih članstva $\vee$ EU. Poslanci so vedno bolj izpostavljeni intenzivnim tokovom informacij, ki prihajajo iz okolja EU, čas odzivanja nanje pa bo vse krajši. To lahko pripelje do tega, da bodo delovali vedno bolj 'reaktivno' kot pa 'aktivno', kar pa si za manjšo in občutljivo državo težko predstavljamo. Posebno vprašanje je število poslancev $v$ državnem zboru, ki je $v$ primerjavi $z$ drugimi parlamenti precej skromno (nekateri pozivi za povečanje števila poslancev so ostali brez širšega odmeva). Zato lahko predpostavljamo, da državni zbor na začetku svojega četrtega mandata in prvega mandata po sprejemu $v$ članstvo Slovenije $\vee$ EU še ni dovolj usposobljen. $V$ razmerah pomanjkanja izkušenj kakor tudi precedenčnih primerov se zanj pravo delo šele začenja. Na drugi strani bi se morali tudi državljani bolj zavedati pomena te njegove nove vloge in priložnosti, ki se ponujajo, da sodeluje pri izvajanju vpliva prek vlade pa tudi v sodelovanju z drugimi parlamenti držav članic. 


\section{Drago Zajc \\ Sposobnost slovenskega parlamenta sodelovati v procesu odločanja na ravni EU}

Dr. Drago Zajc predava predmet 'Sodobni parlamentarizem' na Fakulteti za družbene vede in vodi raziskovalni projekt 'Vloga nacionalnega parlamenta v EU - primer državnega zbora RS'. Je avtor številnih del s področja parlamentarizma, npr. Slovenski parlament v procesu politične modernizacije (1993), Parlamentarno odločanje (1999), Razvoj parlamentarizma (2004), itd.

\section{Literatura in viri}

- Agh, A. (2001): The Euro-Capacity of Small ECE Countries, HCDS, Budapest.

- Dann, P. (2002); Looking through the federal lens: the semi-parliamentary democracy of the EU. Jean Monet working paper, New York School of Law, New York.

- $\quad$ Grad, F.(2003): Nova razmerja med parlamentom in vlado. Podjetje in delo, št. 6-7/2003. Gospodarski vestnik, Ljubljana.

- Igličar, A. (2005): Vpliv evropske zakonodaje na slovenski pravni sistem, v: Slovenija v EU (znanstveni zbornik, ur. D. Zajc in M. Haček), FDV, Ljubljana.

- Igličar, A.(2004): Vpliv evropske zakonodaje na slovenski pravni sistem, v: Slovenija v EU - zmožnosti in priložnosti (znanstveni zbornik, ur. D. Zajc in M. Haček), FDV, Ljubljana.

- Kocjančič R. (2003): Evropska unija med demokratičnostjo in učinkovitostjo, X. dnevi slovenske uprave, zbornik referatov, Fakulteta za upravo.

- Kraševec, T. (2005): The cooperation between the National Assembly of Slovenia and the Slovenian government after EU accession - first experiences, referat na mednarodni konferenci 'Internationalization of Parliaments - Role of National Parliaments in the EU', Državni zbor, april 7.-9., Ljubljana.

- Langhelle, O., Rommetvedt, H. in Zajc, D. (2005): Internationalization of Norwegian Storting and Slovene Državni zbor, Referat na mednarodni konferenci 'Internationalization of Parliaments - Role of National Parliaments in the EU, Državni zbor, 7.-9. Aprila 2005, Državni zbor, Ljubljana.

- Maurer, A. in Wessels, W. (2001): National Parliaments on their Way to European Union: Losers or Latecomers, Nomos, Baden-Baden.

- Norton, Ph. (1995): National Parliaments in the European Union, Frank Cass, London.

- Zajc, D. (2004): Raziskovalno poročilo 'Vloga nacionalnega parlamenta v EU - primer Državnega zbora RS', Fakulteta za družbene vede, Center za politološke raziskave, Ljubljana.

- Zajc, D. (2004): Razvoj parlamentarizma - funkcije sodobnih parlamentov, FDV, Ljubljana. 
Drago Zajc

Sposobnost slovenskega parlamenta sodelovati $v$ procesu odločanja na ravni EU

Pravni viri:

- Zakon o zunanjih zadevah, Uradni list RS, št. 1/1991,

- Zakon o sodelovanju med Državnim zborom RS in Vlado RS v zadevah EU, Uradni list RS, št. 34/2004,

- Poslovnik Državnega zbora RS, členi 154.a - 154.m, (2004), Uradni list RS, Ljubljana. 
Drago Zajc

Sposobnost slovenskega parlamenta sodelovati $v$ procesu odločanja na ravni EU

\section{SUMMARY}

\section{The Capacity of the Slovene Parliament to Influence the Decision Making Process on the EU Level}

Process of European integration has had specific characteristics, being conducted mainly by the initiatives of national political elites and executives. It was directed from above, while the parliaments had only a secondary role and rarely tried to influence explicit European policies. National political and economic elites were fighting for their own interests regardless of eventual opinions of parliaments and general public, which was supposed to support closer integration. Such an 'asymetric' way of interaction created a kind of intergovernmental elite democracy. While the traditional representative democracy with governments directly responsible to the parliaments is stil prevailing in the member states, on the level of EU and its institutions a historically new type of 'delegated democracy' has been invented and institutionalised, consisting of powers which were transferred to it from the national level. What we find in fact is similar to an 'executive federalism' where main actors in the decision making process are institutions with executive power. Decisions which would have been on the national level adopted by the parliaments are taken by the representatives of national governments on the EU level. The whole model resembles to the prescriptions of the consociational democracy where politicies are made in the form of elite agreements and where such agreements instead of democratically agreed and taken decisions hold the whole system together.

The EU legal doctrine has excluded national parliaments from the its institutional framework. The EC/EU Treaty provisions did not determine any specific role of the national parliaments, while the modalities by which the national parliaments participate in the dealing with EU matters were left to member countries. National parliaments were not given any possibility to take part in the process of EU decision making or to intervene directly in the passing of EU legislative acts. This deficiency regarding the national parliaments has caused a number of problems. Marginalisation of national parliaments is an important factor in producing the democratic deficit, besides the problems caused by the general lack of transparency and hardly understandable procedures of the EU institutions. To alleviate this problems the EU brought about the recognition of the 
national parliaments. While the Maastricht's Treaty's Declaration No. 13 on the role of national parliaments made the first step, the Protocol No. 9 of the Amsterdam Treaty determined formally their role of as supervisors of their governments in relation to the EU. The European Council has dealt with their role additionally on its meetings in Nice and in Laeken.

A number of these documents has specifically determined and enlarged possiblities for an involvement of the national parliaments in the process of decision making on the level of the EU, though the indirect way through their governments. A new parliamentary climate has been created favorable for their ingagement. Though the parliaments of the member countries have not used these new possibilities alike. A simple comparison among these parliaments has shown, that their roles of supervisers of their governments have been mainly dependent on a variety of factors: (a) specific constitutional arrangements, determinig the positon of the parliament, (b) traditional consideration of international matters as 'foreign' and therefore dealt primarely by the executive, (c) the way how the division of work among the committees and plenary is implemented, (d) the extent of professional support to the parliamentary body dealing with the EU matters, and (e) the actual awareness among the parliamentarians that the EU matters have actually become 'internal' matters of each EU member country while a number of the 'internal' matters could be internationalised to various extends. On the other side - as practical examples have shown - the actual involvement of the national parliaments has become more effective by the use of an entire range of 'internal' control and cooperation measures, like using the plenary for discussing the EU-related matters, where reports of the government were objects of debates. The efficiency of the national parliaments has been importantly improved also by specialised committees on European Affairs, securing the 'helicopter ' perspective over all EU issues dealt by parliamentary committees which were also expected to follow EU policies in general and to keep themselves informed about the plans of their national ministers. Besides, a number of parliaments has developed new 'International' methods of work', like continous exchange of informations and ideas between national parliaments (speakers, members, secretary-general, civil servants, etc.). These methods made it possible for the speakers to identify issues which deserve special attention by national parliaments at an early stage. 


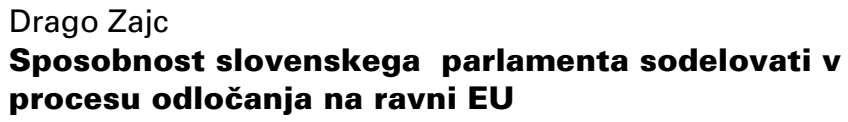

The new EU member states have applied different ways to ensure the control of the parliament over government when it participates in the decision making on the level of the EU. Some of them have determined its role already in the change of constitution by which part of the sovereign rights were transferred to the EU institutions. Some have described the relationship between the parliament and government in special laws determining the role of the committee dealing with EU affairs, all of them amending at the same time their rules of procedure. In comparison with the 'old' member states the new entrant states have had litle opportunity to develop proper working methods in order to control their governments or to cooperate with a government in preparation of positions which should be presented by their government's representatives in the Council of ministers.

Slovenian parliament or its main chamber Državni zbor, insured itself a strong role in relation to the government in the dealing with the EU matters. Such a role, determined already in the new article 3.a, amending the Constitution of Slovenia in 2003, was a consequence of its strong position in the Slovene constitutional design. These constitutional provisions had already determined its influence in process of joining the EU, when Državni zbor had actually discussed and confirmed the negotiating positions as a whole (not only in the Commission for the EU matters or in the Committee for Foreign Affairs). In the second step, taken by the passing of a special Law on Cooperation Between the Državni zbor and the Government of Slovenia in the EU Matters in 2004 this relationship has been additionally determined - the Government of Slovenia has to inform the Državni zbor promptly on all important EU matters and on all procedures from the start when they appear in the form of proposals through discussion when they may be amended or changed. It has to provide Državni zbor with necessary data on the substance and goals of particular proposals and also, with the possible consequences of the proposed acts for the Slovene economy, public administration, environment and the need for additional regulation. Finally, the Government has to propose its own position regarding the proposed EU acts. These legal provisions have undoubtfully allowed the Državni zbor to be informed of all relevant EU issues and to discuss issues which are of real importance for the Slovenes or for the special interests Slovenia 
has regarding the development of particular policies. In order to make the realization of these mutual tasks possible and to enhance cooperaton between the Državni zbor and the Government a division of responsibilities between the plenary and the special Committee on EU matters was made according to the model of Scandinavian parliaments (Finnish Eduskunta). The latter is having the 'helicopter' perspective over the activity over other committees when they are dealing with EU matters, while the plenary can be used as the arena for political debate on behalf of the citizens. According to these provisions some changes of the Rules of procedure had also been made.

These provisions have definitely made possible a strong role of the Slovene Državni zbor in the dealing with the EU matters and increased its 'institutional capacity'. The political scientists are nevertheless aware, that a parliamentary institution with a widest range of responsibilities can not simply adapt to the new supranational surrounding and to a variety of new functions. What the researchers find is on the other side a lack of precedents or a very small amount of accumulated knowledge necessary for the handling of important EU affairs. One can only expect that this knowledge or 'cultural capacity' will increase with the growing awareness of the parliamentary leadership and the individual parlamentarians that the EU matters are in fact becoming internal affairs. The parliamentarians have not yet developed proper contacts with other parlamentarians and parliamentary groups in other parliaments, and do not serve yet as a valuable link between the citizens and EU institutions. The Slovene parliament is like other parliaments of the new entrant states in the Central and Eastern Europe only at the beginning future role and its character is stil going to change. This may happen by intensifying and refining its internal control measures and collaboration activities, combining them with appropriate international measures and activities (maintaining regular contacts with all institutions of the EU, participating at regular meetings of the COSAC or of the chairmen of the relevant committees and at Speakers' Conferences). Only by combining both methods and activities the Slovene parliament may contribute to increase the overall accountability of the EU institutions and help to diminish the democratic deficite of the EU. At this beginning one can only immagine that the process of further Europeanization may allow also that by using properly the international methods, the 'internal' matters may become EU matters as well. 
